\title{
Odpartyjnienie samorządu, ale nie na każdym szczeblu - studium wyborów samorządowych 2018 w województwie śląskim
}

\author{
Non-partisan Local Government, \\ but Not at Every Level - Study of the 2018 Elections \\ in the Silesian Voivodeship
}

\author{
Maciej Marmola* \\ Karolina Kaczmarczyk*
}

\begin{abstract}
Abstrakt
Wybory samorządowe w 2018 roku zostały w dużym stopniu zdominowane przez ogólnopolską rywalizację między rządzącym Prawem i Sprawiedliwością oraz partiami opozycyjnymi. Dodatkowo nowelizacja Kodeksu wyborczego rozszerzyła katalog miast i gmin, w których wybory odbywały się w wielomandatowych okręgach wyborczych z wykorzystaniem metody d'Hondta, co mogło sprzyjać partiom ogólnopolskim. Autorzy prezentowanego artykułu sprawdzają, w jakim stopniu oddziaływało to na poziom upartyjnienia organów samorządu, które w warunkach polskich postrzegane są
\end{abstract}

\begin{abstract}
The 2018 local government elections were largely dominated by the nationwide competition between the ruling Law and Justice (PiS) and opposition parties. In addition, the amendment to the Electoral Code expanded the volume of cities and municipalities where elections were held in multi-member constituencies using the d'Hondt method, which could favor nationwide parties. The presented article analyzes the extent to which this influenced the level of politicization of the Polish local government, which was commonly perceived as a sphere of influence of local electoral committees.
\end{abstract}

* Uniwersytet Śląski w Katowicach (maciej.marmola@us.edu.pl) iD https://orcid. org/0000-0003-1911-1125

** Uniwersytet Śląski w Katowicach (karolina.kaczmarczyk@onet.pl) iD https://orcid. org/0000-0001-5621-7338 
raczej jako strefa wpływu komitetów lokalnych. W tym celu przeanalizowali poziom poparcia dla partii politycznych i komitetów lokalnych w 167 gminach i miastach województwa śląskiego. Badanie potwierdziło pozytywny związek między liczbą mieszkańców danej gmin/miasta i poziomem upartyjnienia jednostek samorządu. Pogłębiona analiza ukazała, że komitety lokalne i bezpartyjni kandydaci na urząd wójta i burmistrza dominują w mniejszych gminach i miastach (do 100 tys. mieszkańców), a największy upartyjnieniem charakteryzują się miasta na prawach powiatu.

Słowa kluczowe: wybory samorządowe, polityce lokalni, partie polityczne, odpartyjnienie
For this purpose, we examine the level of support for political parties and local committees in 167 municipalities and cities of the Silesian Voivodeship. The study confirms a positive relationship between the level of party politicization of local governments and the inhabitants' number in the municipality. An in-depth analysis shows that local committees and non-party candidates for the mayor's office definitely dominate in smaller municipalities and cities (up to 100,000 inhabitants). In contrast, the largest cities with poviat rights are characterized by a greater degree of politicization.

Keywords: local elections, local politics, political parties, non-partisanship

\section{Wprowadzenie}

Wybory do rad gmin w 1990 roku były pierwszą w pełni rywalizacyjną elekcją w dziejach III Rzeczypospolitej Polskiej. Od tego czasu stopniowo wzrasta znaczenie samorządu terytorialnego. Widać to choćby na przykładzie wyborów samorządowych, które zyskują coraz większe zainteresowanie elektoratu ${ }^{3}$. Charakterystyczną cechą elekcji samorządowych jest występowanie w nich podmiotów lokalnych, co wiąże się z udziałem w polityce samorządowej bezpartyjnych polityków. Choć partie polityczne odgrywają znaczącą rolę w życiu politycznym, to w wyborach samorządowych nie są głównym podmiotem rywalizacji wyborczej. Prowadzone badania wskazują na to, że w polskim samorządzie partie ogólnokrajowe mają dużo mniejszy udział we władzy niż w większości państw Europy (Gendźwiłł, Żółtak, 2020).

Wyjaśnienia stosunkowo niskiego poziomu upartyjnienia polskiego samorządu można zasadniczo doszukiwać się w czynnikach natury społecznej i politycznej. Po pierwsze, może on się wiązać z: niewielkim zaufaniem społecznym do partii politycznych (CBOS, 2020), coraz niższym stopniem identyfikacji partyjnej wśród polskich wyborców (CBOS, 2019) oraz brakiem poczucia, że partie

${ }^{3}$ Od 2002 roku zauważalny jest nieustanny wzrost frekwencji wyborczej w wyborach samorządowych. Ponadto, obywatele stopniowo przestają postrzegać elekcję samorządową w kategoriach „wyborów drugorzędnych” (second order elections). Według ostatnich badań zaczynają nawet przypisywać tej elekcji większą rangę niż wyborom parlamentarnym czy prezydenckim (CBOS, 2018; Gendźwiłł, Żerkowska-Balas, 2018, s. 4-5). 
polityczne reprezentują interesy obywateli (Marmola, 2020). Skutecznie odstrasza to część polityków szczebla lokalnego od startowania pod szyldem „nielubianych" partii ogólnopolskich, który w elekcji samorządowej może stanowić polityczny balast. Często nawet członkowie partii politycznych decydują się zresztą na tworzenie własnych pozornie bezpartyjnych komitetów lokalnych (Drzonek, 2019, s. 127), starając się tym samym uzyskać wyborczą premię za wykreowanie siebie i swojego środowiska jako niezależnych polityków szczebla lokalnego. Po drugie, partiom politycznym nie sprzyja personalizacja elekcji lokalnych, ugruntowana w 2002 roku wprowadzeniem bezpośredniego wyboru wójtów, burmistrzów i prezydentów miast (Gendźwiłł, Żółtak, 2020). Czynnik ten zachęca wręcz do budowania tzw. komitetów prezydenckich czy komitetów wodzowskich, których poparcie zależy przede wszystkich od pozycji lokalnych włodarzy (Gendźwiłł, 2010; Gendźwiłł, Swianiewicz, 2017). Dominację „lokalnych partii władzy" może dodatkowo pogłębiać system wyborczy. W tym kontekście warto zauważyć, że wybory w jednomandatowych okręgach wyborczych (JOW) w warunkach polskiego samorządu zwykle umacniały pozycję lokalnego inkumberta oraz jego środowiska politycznego (Flis, Stolicki, 2019) i ograniczały obecność przedstawicieli partii politycznych w samorządzie gminnym (Gendźwiłł, Żołtak, 2016). Wybory samorządowe w 2018 roku były pierwszymi, w których zastosowano znowelizowany sposób wyboru składu rad miast i gmin. Nowelizacja Kodeksu wyborczego wprowadzona Ustawą z dnia 11 stycznia 2018 roku o zmianie niektórych ustaw w celu zwiększenia udziału obywateli w procesie wybierania, funkcjonowania i kontrolowania niektórych organów publicznych (Dz.U. 2018, poz. 130) poszerzyła katalog jednostek samorządu terytorialnego, w których wybory odbywają się w wielomandatowych okręgach wyborczych z zastosowaniem formuły d'Hondta. Takie rozwiązania dotyczyły sejmików województw, rad powiatów, rad miast na prawach powiatu oraz wszystkich organów stanowiących w gminach liczących powyżej 20000 mieszkańców. W odniesieniu do gmin o liczbie mieszkańców poniżej tej liczby pozostano przy formule większościowej i określono, że wybory w tych gminach będą odbywać się w JOW-ach (Balicki 2018, s. 63). Tym samym nowelizacja wpłynęła na modyfikację formuły wyborczej w 276 jednostkach samorządu terytorialnego, w których JOW-y zastąpiono systemem proporcjonalnym (PAP, 2018). Zmiana ta w połączeniu ze zmniejszeniem wielkości okręgu wyborczego miała ograniczyć potencjał polityczny komitetów tworzonych przez włodarzy gmin i zwiększyć szanse innych podmiotów, w tym ogólnopolskich partii politycznych (zob. np. Flis, 2017). W ten sposób nowelizacja potencjalnie powinna skutkować większą aktywnością i lepszym wynikiem wyborczych partii ogólnopolskich w gminach, w których wprowadzono system proporcjonalny. Po trzecie, elekcje na poziomie lokalnym znacząco różnią się od wyborów ogólnokrajowych pod względem wzorców rywalizacji politycznej. W większym stopniu rywalizacja ta ma bowiem charakter aideologiczny i skupia się na realnych potrzebach wspólnot lokalnych odnoszących się 
do infrastruktury czy podstawowych usług publicznych. Po czwarte wreszcie, za czynnik ograniczający możliwość zaistnienia partii politycznych na poziomie samorządu można uznać charakterystyczną dla wszystkich państw Europy Środkowej i Wschodniej niestabilność systemów partyjnych i samych partii na poziomie politycznego centrum (Marmola, 2019, s. 137). W sytuacji, gdy partie polityczne mają spore problemy z utrzymaniem statusu formacji relewantnych na poziomie ogólnokrajowym, trudno zakładać, że będą w stanie stworzyć efektywne i trwałe struktury lokalne.

Celem autorów prezentowanego artykułu jest sprawdzenie poziomu bezpartyjności organów stanowiących oraz wykonawczych w gminach i miastach województwa śląskiego po wyborach samorządowych w 2018 roku. Wydaje się to szczególnie istotne ze względu na fakt, że elekcja ta cieszyła się większym niż dotychczas zainteresowaniem partii ogólnopolskich, a z racji, że były to pierwsze wybory powszechne od jesieni 2015 roku, część wyborców i podmiotów polityki mogła w większym stopniu kierować się w nich logiką partyjną, utożsamianą z rywalizacją rządzącego Prawa i Sprawiedliwości oraz formacji opozycyjnych. Mogło to tym samym skutkować lepszymi rezultatami wyborczymi partii politycznych (co zresztą widać we wzroście ich dominacji na arenie sejmikowej) oraz nadaniem tej elekcji specyficznej, plebiscytarnej rangi, która w konsekwencji może ograniczać diagnozowane przez badaczy odpartyjnienie sfery samorządu.

\section{Metodologia}

Przedmiot niniejszej analizy stanowiły: liczba komitetów lokalnych i poparcie dla nich w wyborach do rad gmin i miast oraz na urzędy wójta, burmistrza i prezydenta miasta w 2018 roku w 167 gminach i miastach województwa śląskiego. Na potrzeby badań zdecydowano się podzielić startujące komitety wyborcze na komitety partyjne i komitety lokalne. Zdając sobie sprawę z problemów, jakich nastręcza ocena stopnia bezpartyjności podmiotów startujących w elekcji samorządowej w procesie konceptualizacji komitetów lokalnych, sformułowano definicję negatywną tychże komitetów. Tym samym do tego grona zaliczono wszystkie ugrupowania polityczne startujące w badanej elekcji, które nie były komitetami partii ogólnopolskich i regionalnych. Wśród komitetów lokalnych znalazły się więc komitety:

- lokalnych aktorów politycznych (utworzone przez wójtów, burmistrzów lub prezydentów bądź też przez rozpoznawalnych lokalnych działaczy politycznych),

- lokalnych organizacji społecznych (będące zwykle emanacją lokalnych stowarzyszeń), 
- pozornie bezpartyjne (założone przez członków partii politycznych, jednak zarejestrowane jako formacje lokalne).

Głównym celem badawczym prezentowanego artykułu było sprawdzenie relacji między wielkością miasta lub gminy (wyrażoną liczbą mieszkańców) a poziomem upartyjnienia organów stanowiących i wykonawczych gmin/miast. W ramach badań diagnozowano, czy istnieje związek między liczbą mieszkańców a liczbą wszystkich startujących komitetów, liczbą komitetów lokalnych, liczbą komitetów partyjnych, poparciem dla kandydatów komitetów lokalnych, liczbą mandatów obsadzonych przez komitety lokalne oraz liczbą mandatów obsadzonych przez komitety partyjne. W tym celu wyliczono współczynniki korelacji Pearsona między liczbą mieszkańców a średnimi wskazanych uprzednio zmiennych obliczonych dla wszystkich 167 miast i gmin województwa śląskiego. Założono przy tym, że mniejsza liczba mieszkańców powinna wiązać się $\mathrm{z}$ mniejszym poziomem upartyjnienia rad gmin, utożsamianym $\mathrm{w}$ tych badaniach z: większą liczbą startujących komitetów lokalnych, lepszymi wynikami wyborczymi oraz większą liczbą mandatów tych formacji. W celu pogłębienia badań zdecydowano się również na przeanalizowanie zebranych danych $\mathrm{w}$ odniesieniu do trzech kryteriów: (1) rodzaju gminy (gmina wiejska, gmina miejsko -wiejska, gmina miejska, miasto na prawach powiatu); (2) wielkości gminy (do 20 000, 20 001-50 000, 50 001-100 000, powyżej 100000 mieszkańców) oraz (3) systemu wyborczego. W drugiej części badań skupiono się natomiast na organie wykonawczym. Tym razem ukazano liczbę i odsetek partyjnych oraz bezpartyjnych wójtów, burmistrzów i prezydentów miast w odniesieniu do rodzaju i wielkości gminy.

\section{Wyniki badań - rady gmin i miast}

Przeprowadzona analiza potwierdziła kilka istotnych zależności między liczbą mieszkańców a badanymi zmiennymi. Odnotowano silną dodatnią korelację między liczbą mieszkańców a liczbą komitetów partyjnych startujących w elekcji w danej gminie/mieście $(r=0,654)$ oraz liczbą mandatów obsadzonych przez te komitety $(r=0,773)$. Oznacza to, że w gminach i miastach o większej liczbie mieszkańców startuje więcej komitetów partyjnych oraz uzyskują one więcej mandatów w organach stanowiących. Związek o słabej sile zidentyfikowano również $\mathrm{w}$ odniesieniu do liczby wszystkich startujących komitetów $(r=0,225)$. Ujemną wartość współczynnika korelacji otrzymano natomiast w odniesieniu do liczby mieszkańców gminy/miasta i łącznego poparcia dla kandydatów komitetów lokalnych $(r=-0,568)$ oraz liczby mandatów zdobytych przez te komitety $(r=-0,340)$. Tym samym potwierdzono, że istnieje istotny 
związek (o umiarkowanej sile) między tymi zmiennymi. Oznacza to, że komitety lokalne uzyskiwały lepsze wyniki wyborcze w gminach o niższej liczbie mieszkańców.

Tabela 1

Wartości współczynników korelacji między badanymi zmiennymi

\begin{tabular}{|l|c|c|c|c|c|c|}
\cline { 2 - 6 } \multicolumn{1}{c|}{} & $\begin{array}{c}\text { Liczba } \\
\text { wszystkich } \\
\text { startujących } \\
\text { komitetów }\end{array}$ & $\begin{array}{c}\text { Liczba } \\
\text { komitetów } \\
\text { lokalnych }\end{array}$ & $\begin{array}{c}\text { Liczba } \\
\text { komitetów } \\
\text { partyjnych } \\
\text { partie ogólno- } \\
\text { polskie } \\
\text { i regionalne) }\end{array}$ & $\begin{array}{c}\text { Lączne } \\
\text { poparcie dla } \\
\text { kandydatów } \\
\text { komitetów } \\
\text { lokalnych w \% }\end{array}$ & $\begin{array}{c}\text { Liczba } \\
\text { mandatów } \\
\text { obsadzonych } \\
\text { przez komitety } \\
\text { lokalne }\end{array}$ & $\begin{array}{c}\text { Liczba } \\
\text { mandatów } \\
\text { obsadzonych } \\
\text { przez komitety } \\
\text { partyjne }\end{array}$ \\
\hline $\begin{array}{l}\text { Liczba } \\
\text { mieszkańców } \\
(30.06 .2016)\end{array}$ & $0,225^{* *}$ & $-0,127$ & $0,654 * * *$ & $-0,568^{* * *}$ & $-0,340^{* * *}$ & $0,773 * * *$ \\
\hline
\end{tabular}

$* p \leq 0,05 * * p \leq 0,01 * * * p \leq 0,001$

Źródło: Opracowanie własne na podstawie przeprowadzonych badań.

W celu pogłębienia wyników analizy i ukazania skali poparcia dla komitetów lokalnych i partyjnych w województwie śląskim analizowane dane odniesiono do rodzaju gminy i jej wielkości. Uzyskane wyniki potwierdzają wykazane wcześniej zależności. Największa liczba komitetów lokalnych startowała z gmin do 20000 mieszkańców (średnio 3,97 komitetów), a najmniejsza - w jednostkach samorządu od 50001 do 100000 mieszkańców oraz tych liczących powyżej 100000 mieszkańców (średnio 3 komitety). Największą aktywność komitetów partyjnych odnotowano $\mathrm{z}$ kolei w największych $\mathrm{z}$ badanych jednostek (średnio 4,33 komitetu partyjnego). Dla porównania $\mathrm{w}$ gminach i miastach do 20000 mieszkańców listy rejestrowało średnio 1,17 komitetu partyjnego.

Podobnie prezentują się dane odnoszące się do poparcia i liczby mandatów dla badanych komitetów. W gminach i miastach do 20000 mieszkańców kandydaci komitetów lokalnych zdobywali średnio przeszło cztery piąte głosów (dokładnie 82,75\%). Nieco gorzej komitety te radziły sobie w jednostkach samorządu z przedziału 20 001-50 000 oraz 50 001-100 000 mieszkańców, w których przedstawiciele tych komitetów zdobywali łącznie odpowiednio 72,59\% oraz $61,64 \%$ ważnie oddanych głosów. Zdominowane przez partie ogólnopolskie okazały się natomiast miasta powyżej 100000 mieszkańców, w których komitety lokalne uzyskiwały poparcie mniej niż jednej trzeciej wyborców.

Analogiczne zróżnicowanie widoczne jest również w odniesieniu do pozycji komitetów lokalnych w radach miast i gmin. I tym razem okazało się, że na scenach politycznych najmniejszych gmin dominują formacje lokalne, natomiast w miastach powyżej 100000 mieszkańców wyborcy i sami politycy w większym stopniu kierują się logiką partyjną, o czym świadczy dominacja partii ogólnopolskich w organach stanowiących. 
Tabela 2

Średnia liczba startujących komitetów, komitetów lokalnych i partyjnych, poparcia dla kandydatów komitetów lokalnych oraz liczby mandatów obsadzonych przez komitety lokalne i partyjne w odniesieniu do wielkości miasta/gminy

\begin{tabular}{|c|c|c|c|c|c|c|}
\hline $\begin{array}{c}\text { Wielkość } \\
\text { miasta/gminy }\end{array}$ & $\begin{array}{c}\text { Liczba } \\
\text { wszystkich } \\
\text { startujących } \\
\text { komitetów }\end{array}$ & $\begin{array}{c}\text { Liczba } \\
\text { komitetów } \\
\text { lokalnych }\end{array}$ & \begin{tabular}{|c|} 
Liczba \\
komitetów \\
partyjnych \\
(partie \\
ogólnopolskie \\
i regionalne)
\end{tabular} & $\begin{array}{c}\text { Łączne } \\
\text { poparcie dla } \\
\text { kandydatów } \\
\text { komitetów } \\
\text { lokalnych w \% }\end{array}$ & $\begin{array}{c}\text { Liczba } \\
\text { mandatów } \\
\text { obsadzonych } \\
\text { przez komitety } \\
\text { lokalne }\end{array}$ & $\begin{array}{c}\text { Liczba } \\
\text { mandatów } \\
\text { obsadzonych } \\
\text { przez komitety } \\
\text { partyjne }\end{array}$ \\
\hline $\begin{array}{l}\text { Do } 20000 \\
\text { mieszkańców } \\
(N=126)\end{array}$ & $\begin{array}{c}5,10 \\
(2,662)\end{array}$ & $\begin{array}{c}3,97 \\
(2,183)\end{array}$ & $\begin{array}{c}1,17 \\
(1,049)\end{array}$ & $\begin{array}{c}82,75 \\
(19,50)\end{array}$ & $\begin{array}{c}13,17 \\
(2,994)\end{array}$ & $\begin{array}{c}1,83 \\
(2,994)\end{array}$ \\
\hline $\begin{array}{c}20001-50000 \\
\text { mieszkańców } \\
(N=17)\end{array}$ & $\begin{array}{c}4,88 \\
(1,364)\end{array}$ & $\begin{array}{c}3,29 \\
(1,105)\end{array}$ & $\begin{array}{c}1,59 \\
(0,939)\end{array}$ & $\begin{array}{c}72,59 \\
(14,45)\end{array}$ & $\begin{array}{c}15,76 \\
(3,133)\end{array}$ & $\begin{array}{c}5,24 \\
(3,133)\end{array}$ \\
\hline $\begin{array}{c}50 \text { 001-100 } 000 \\
\text { mieszkańców } \\
(N=12)\end{array}$ & $\begin{array}{c}5,33 \\
(1,073)\end{array}$ & $\begin{array}{c}3,00 \\
(0,953)\end{array}$ & $\begin{array}{c}2,33 \\
(0,985)\end{array}$ & $\begin{array}{c}61,64 \\
(18,96)\end{array}$ & $\begin{array}{c}14,17 \\
(5,078)\end{array}$ & $\begin{array}{c}8,50 \\
(4,982)\end{array}$ \\
\hline $\begin{array}{c}\text { Powyżej } \\
100000 \\
\text { mieszkańców } \\
(N=12)\end{array}$ & $\begin{array}{c}7,00 \\
(1,758)\end{array}$ & $\begin{array}{c}3,00 \\
(1,206)\end{array}$ & $\begin{array}{c}4,33 \\
(1,303)\end{array}$ & $\begin{array}{c}32,73 \\
(11,35)\end{array}$ & $\begin{array}{c}7,42 \\
(3,919)\end{array}$ & $\begin{array}{c}18,08 \\
(4,274)\end{array}$ \\
\hline
\end{tabular}

W nawiasach wartości odchylenia standardowego.

Źródło: opracowanie własne na podstawie przeprowadzonych badań.

Wskazane tendencje (choć z nieco mniejszym natężeniem) znajdują swoje odzwiedlenie w odniesieniu do rodzaju gminy. Co ciekawe, największą liczbą startujących komitetów lokalnych charakteryzują się nie gminy wiejskie (średnio $3,72)$, lecz gminy miejsko-wiejskie $(4,38)$ oraz miejskie $(4,03)$. Najmniej takich komitetów zarejestrowano natomiast $\mathrm{w}$ miastach na prawach powiatu (średnio 2,84), w których za to największym zainteresowaniem cieszyło się tworzenie list partyjnych (średnio 3,74 komitetów partyjnych startujących w badanej elekcji).

Pewne różnice widoczne są także w odniesieniu do skali poparcia komitetów lokalnych oraz liczby mandatów obsadzonych przez ich przedstawicieli. Okazuje się bowiem, że łączne poparcie dla kandydatów startujących z list lokalnych komitetów wyborczych w gminach wiejskich, miejsko-wiejskich i miejskich jest niemal identyczne (mniej więcej 80\% głosów). Większych różnic między tymi jednostkami samorządu nie widać również w odniesieniu do liczby mandatów w organach stanowiących. Na tym tle dużo gorzej prezentuje się skala poparcia dla komitetów lokalnych w miastach na prawach powiatu. W miastach tych zdobywały one bowiem średnio zaledwie 41,20\% głosów i znacząco mniej mandatów niż komitety partyjne. Co warte podkreślenia, obie te wartości są jednak wyższe niż w miastach powyżej 100000 mieszkańców. Może to sugerować, że pozycja komitetów lokalnych w większym stopniu zależy właśnie od 
liczby mieszkańców, a od nie statusu danej jednostki samorządu terytorialnego. W mniejszych miastach na prawach powiatu (takich jak np. Świętochłowice, Piekary Śląskie czy Żory) poparcie dla komitetów lokalnych jest bowiem znacząco większe niż w największych miastach (np. w Częstochowie, Katowicach czy Sosnowcu).

Tabela 3

Średnia liczba startujących komitetów, komitetów lokalnych i partyjnych, poparcia dla kandydatów komitetów lokalnych oraz liczby mandatów obsadzonych przez komitety lokalne i partyjne w odniesieniu do rodzaju gminy

\begin{tabular}{|c|c|c|c|c|c|c|}
\hline Rodzaj gminy & $\begin{array}{c}\text { Liczba } \\
\text { wszystkich } \\
\text { startujących } \\
\text { komitetów }\end{array}$ & $\begin{array}{c}\text { Liczba } \\
\text { komitetów } \\
\text { lokalnych }\end{array}$ & $\begin{array}{c}\text { Liczba } \\
\text { komitetów } \\
\text { partyjnych } \\
\text { (partie } \\
\text { ogólnopolskie } \\
\text { i regionalne) }\end{array}$ & $\begin{array}{c}\text { Łączne } \\
\text { poparcie dla } \\
\text { kandydatów } \\
\text { komitetów } \\
\text { lokalnych w \% }\end{array}$ & $\begin{array}{c}\text { Liczba } \\
\text { mandatów } \\
\text { obsadzonych } \\
\text { przez komitety } \\
\text { lokalne }\end{array}$ & $\begin{array}{c}\text { Liczba } \\
\text { mandatów } \\
\text { obsadzonych } \\
\text { przez komitety } \\
\text { partyjne }\end{array}$ \\
\hline $\begin{array}{c}\text { Gmina } \\
\text { wiejska } \\
(N=96)\end{array}$ & $\begin{array}{c}4,86 \\
(2,602)\end{array}$ & $\begin{array}{c}3,72 \\
(2,066)\end{array}$ & $\begin{array}{c}1,19 \\
(1,089)\end{array}$ & $\begin{array}{l}81,97 \\
(2,68)\end{array}$ & $\begin{array}{c}13,07 \\
(3,410)\end{array}$ & $\begin{array}{c}2,05 \\
(3,278)\end{array}$ \\
\hline $\begin{array}{l}\text { Gmina } \\
\text { miejsko- } \\
\text { wiejska } \\
(N=21)\end{array}$ & $\begin{array}{c}5,67 \\
(2,726)\end{array}$ & $\begin{array}{c}4,38 \\
(2,334)\end{array}$ & $\begin{array}{c}1,29 \\
(1,102)\end{array}$ & $\begin{array}{c}79,46 \\
(17,44)\end{array}$ & $\begin{array}{c}13,76 \\
(2,022)\end{array}$ & $\begin{array}{c}2,76 \\
(2,809)\end{array}$ \\
\hline $\begin{array}{l}\text { Gmina } \\
\text { miejska } \\
(N=31)\end{array}$ & $\begin{array}{c}5,39 \\
(1,961)\end{array}$ & $\begin{array}{c}4,03 \\
(1,871)\end{array}$ & $\begin{array}{c}1,35 \\
(0,877)\end{array}$ & $\begin{array}{c}79,76 \\
(16,38)\end{array}$ & $\begin{array}{c}14,94 \\
(3,054)\end{array}$ & $\begin{array}{c}3,16 \\
(3,908)\end{array}$ \\
\hline $\begin{array}{l}\text { Miasto na } \\
\text { prawach } \\
\text { powiatu } \\
(N=19)\end{array}$ & $\begin{array}{c}6,37 \\
(1,739)\end{array}$ & $\begin{array}{c}2,84 \\
(1,015)\end{array}$ & $\begin{array}{c}3,74 \\
(1,368)\end{array}$ & $\begin{array}{c}41,20 \\
(17,03)\end{array}$ & $\begin{array}{c}9,47 \\
(4,846)\end{array}$ & $\begin{array}{c}15,00 \\
(5,972)\end{array}$ \\
\hline
\end{tabular}

W nawiasach wartości odchylenia standardowego.

Źródło: Opracowanie własne na podstawie przeprowadzonych badan.

W kontekście zmian w sposobie przeprowadzenia wyborów zebrane dane podzielono na dwie kategorie - gmin i miast, w których obowiązywała formuła proporcjonalna oraz tych gmin, gdzie wybory odbywały się w JOW-ach. Uzyskane rezultaty wpisują się $\mathrm{w}$ przedstawione wcześniej wnioski. W tych jednostkach, gdzie zastosowano okręgi wielomandatowe i formułę d'Hondta, startowało więcej komitetów partyjnych (średnio 2,61 komitetu przy 1,17 startujących w JOW), a kandydaci komitetów lokalnych zdobywali mniejsze poparcie (średnio 57,72\% głosów) niż w gminach, w których wybierano w JOW (średnio $82,75 \%$ głosów). Należy jednak podkreślić, że w obu kategoriach gmin lepsze rezultaty (także pod względem mandatowym) uzyskiwały komitety lokalne. 
W celu uchwycenia oddziaływania wprowadzonych zmian analizie poddano również wyniki w tych miastach i gminach, gdzie formułę proporcjonalną zaimplementowano w 2018 roku oraz w miastach na prawach powiatu, w których rozwiązanie to funkcjonowało już wcześniej. Okazuje się, że obie kategorie różniły się diametralnie pod względem liczby startujących komitetów lokalnych oraz ich poparcia. W jednostkach, gdzie w 2018 roku zmieniono formułę wyborczą, w elekcji startowało średnio 3,36 komitetów lokalnych (w miastach na prawach powiatu średnio 2,84 ), a ich przedstawiciele zdobywali przeciętnie $71,99 \%$ głosów (w miastach na prawach powiatu było to zaledwie 41,20\%).

Tabela 4

Średnia liczba startujących komitetów, komitetów lokalnych i partyjnych, poparcia dla kandydatów komitetów lokalnych oraz liczby mandatów obsadzonych przez komitety lokalne i partyjne w odniesieniu do formuły wyborczej

\begin{tabular}{|c|c|c|c|c|c|c|}
\hline Rodzaj gminy & $\begin{array}{c}\text { Liczba } \\
\text { wszystkich } \\
\text { startujących } \\
\text { komitetów }\end{array}$ & $\begin{array}{c}\text { Liczba } \\
\text { komitetów } \\
\text { lokalnych }\end{array}$ & $\begin{array}{c}\text { Liczba } \\
\text { komitetów } \\
\text { partyjnych } \\
\text { (partie } \\
\text { ogólnopolskie } \\
\text { i regionalne) } \\
\end{array}$ & $\begin{array}{c}\text { Łączne } \\
\text { poparcie dla } \\
\text { kandydatów } \\
\text { komitetów } \\
\text { lokalnych w \% }\end{array}$ & $\begin{array}{c}\text { Liczba } \\
\text { mandatów } \\
\text { obsadzonych } \\
\text { przez komitety } \\
\text { lokalne }\end{array}$ & $\begin{array}{c}\text { Liczba } \\
\text { mandatów } \\
\text { obsadzonych } \\
\text { przez komitety } \\
\text { partyjne }\end{array}$ \\
\hline $\begin{array}{l}\text { Wybory } \\
\text { w JOW-ie } \\
(N=126)\end{array}$ & $\begin{array}{c}5,10 \\
(1,655)\end{array}$ & $\begin{array}{c}3,97 \\
(2,183)\end{array}$ & $\begin{array}{c}1,17 \\
(1,049)\end{array}$ & $\begin{array}{c}82,75 \\
(19,50)\end{array}$ & $\begin{array}{c}13,17 \\
(2,994)\end{array}$ & $\begin{array}{c}1,83 \\
(2,994)\end{array}$ \\
\hline $\begin{array}{c}\text { Formuła } \\
\text { proporcjonalna } \\
(N=41)\end{array}$ & $\begin{array}{c}5,63 \\
(2,662)\end{array}$ & $\begin{array}{c}3,12 \\
(1,077)\end{array}$ & $\begin{array}{c}2,61 \\
(1,563)\end{array}$ & $\begin{array}{c}57,72 \\
(22,45)\end{array}$ & $\begin{array}{c}12,85 \\
(5,313)\end{array}$ & $\begin{array}{c}9,95 \\
(6,760)\end{array}$ \\
\hline \multicolumn{7}{|c|}{ formuła proporcjonalna $(N=41)$} \\
\hline $\begin{array}{c}\text { Formuła } \\
\text { proporcjonalna } \\
\text { od } 2018 \text { roku } \\
(N=22)\end{array}$ & $\begin{array}{c}5,00 \\
(1,309)\end{array}$ & $\begin{array}{c}3,36 \\
(1,093)\end{array}$ & $\begin{array}{c}1,64 \\
(0,953)\end{array}$ & $\begin{array}{c}71,99 \\
(15,84)\end{array}$ & $\begin{array}{c}15,77 \\
(3,791)\end{array}$ & $\begin{array}{c}5,59 \\
(3,673)\end{array}$ \\
\hline $\begin{array}{l}\text { Miasta na pra- } \\
\text { wach powiatu } \\
\quad(N=19)\end{array}$ & $\begin{array}{c}6,37 \\
(1,739)\end{array}$ & $\begin{array}{c}2,84 \\
(1,015)\end{array}$ & $\begin{array}{c}3,74 \\
(1,368)\end{array}$ & $\begin{array}{c}41,20 \\
(17,03)\end{array}$ & $\begin{array}{c}9,47 \\
(4,846)\end{array}$ & $\begin{array}{c}15,00 \\
(5,972)\end{array}$ \\
\hline
\end{tabular}

W nawiasach wartości odchylenia standardowego.

Źródło: Opracowanie własne na podstawie przeprowadzonych badan.

Wyraźnych różnic nie widać również w sytuacji, gdy porównamy wyniki wyborcze z 2014 i 2018 roku w gminach, w których zmieniono sposób wyboru składu rad. W tym kontekście można jednak mówić o pewnym osłabieniu pozycji komitetów lokalnych, na przestrzeni bowiem tych dwóch elekcji nastąpił nieznaczny spadek odsetka głosów dla kandydatów komitetów lokalnych (średnio z 78,18 do 71,99\%), odsetka mandatów obsadzonych przez komitety lokalne (średnio z 85,03 do 73,77\%) oraz średniej liczby startujących komitetów lokal- 
nych (z 7,18 do 3,36). Jednocześnie nieco bardziej aktywne w tych jednostkach samorządu stały się komitety partyjne (wzrost ich obecności z 1,64 do 2,55).

Biorąc pod uwagę specyficzny (zdominowany przez logikę rywalizacji ogólnopolskiej) charakter wyborów z 2018 roku, trudno jednoznacznie uznać te zmiany za skutek uboczny modyfikacji ordynacji. Bezsprzecznie jednak modyfikacja ta wpłynęła na strategie komitetów lokalnych, które wcześniej (w warunkach JOW) często wystawiały kandydatów tylko w jednym okręgu. Kandydaci tworzący tego typu komitety, chcąc nadal liczyć się w grze o mandat wyborczy, musieli w zmienionych warunkach instytucjonalnych decydować się bowiem na skonsolidowanie swoich sił i start w ramach wspólnych inicjatyw lokalnych.

Do ciekawych wniosków prowadzi również pogłębiona analiza uwzględniająca konkretne gminy (tabela 5). Wynika z niej, że w niektórych z tych jednostek samorządu po zmianie ordynacji nie tylko pozycja komitetów lokalnych nie osłabła, ale nawet komitety te poprawiły swój wynik wyborczy i mandatowy z elekcji z 2014 roku. Z takim zjawiskiem mieliśmy do czynienia na przykład w Będzinie czy Czeladzi. W tych miastach umocniły się wpływy lokalnych „komitetów wodzowskich" (KWW Łukasza Komoniewskiego i KWW Zbigniewa Szaleńca).

Tabela 5

Średnia liczba komitetów lokalnych i partyjnych, odsetka poparcia dla kandydatów komitetów lokalnych oraz odsetka mandatów obsadzonych przez komitety lokalne w gminach, w których w 2018 roku zmieniono formułę wyborczą

\begin{tabular}{|l|c|c|c|c|c|c|c|c|}
\hline \multicolumn{1}{|c|}{ Gmina } & $\begin{array}{c}\text { Eączny } \\
\text { odsetek } \\
\text { poparcia } \\
\text { dla kan- } \\
\text { dydatów } \\
\text { komitetów } \\
\text { lokalnych } \\
2018\end{array}$ & $\begin{array}{c}\text { Lączny } \\
\text { odsetek } \\
\text { poparcia } \\
\text { dla kan- } \\
\text { dydatów } \\
\text { komitetów } \\
\text { lokalnych } \\
2014\end{array}$ & $\begin{array}{c}\text { Liczba } \\
\text { komitetów } \\
\text { lokalnych } \\
2018\end{array}$ & $\begin{array}{c}\text { Liczba } \\
\text { komitetów } \\
\text { lokalnych } \\
2014\end{array}$ & $\begin{array}{c}\text { Liczba } \\
\text { pozostałych } \\
\text { komitetów } \\
2018\end{array}$ & $\begin{array}{c}\text { Liczba } \\
\text { pozostałych } \\
\text { komitetów } \\
2014\end{array}$ & $\begin{array}{c}\text { Odsetek } \\
\text { mandatów } \\
\text { obsadzo- } \\
\text { nych przez } \\
\text { komitety } \\
\text { lokalne } \\
2018\end{array}$ & $\begin{array}{c}\text { Odsetek } \\
\text { mandatów } \\
\text { obsadzo- } \\
\text { nych przez } \\
\text { komitety } \\
\text { lokalne } \\
2014\end{array}$ \\
\hline Będzin & 83,12 & 72,25 & 3 & 14 & 1 & 2 & 86,96 & 78,26 \\
\hline Cieszyn & 80,39 & 79,78 & 5 & 6 & 1 & 3 & 80,95 & 85,71 \\
\hline $\begin{array}{l}\text { Czechowice- } \\
\text { Dziedzice }\end{array}$ & 83,54 & 79,75 & 3 & 4 & 1 & 4 & 85,71 & 95,24 \\
\hline Czeladź & 71,3 & 54,43 & 2 & 11 & 3 & 3 & 80,95 & 33,33 \\
\hline $\begin{array}{l}\text { Czerwionka- } \\
\text { Leszczyny }\end{array}$ & 74,95 & 85,98 & 4 & 6 & 1 & 3 & 76,19 & 95,24 \\
\hline Gorzyce & 79,13 & 96,19 & 2 & 5 & 1 & 1 & 85,71 & 95,24 \\
\hline Jasienica & 100,00 & 85,71 & 2 & 5 & 0 & 2 & 100,00 & 95,24 \\
\hline Kłobuck & 52,94 & 46,08 & 2 & 6 & 3 & 5 & 61,90 & 71,43 \\
\hline Knurów & 65,75 & 92,82 & 4 & 10 & 2 & 2 & 66,67 & 90,48 \\
\hline Lubliniec & 82,52 & 100 & 2 & 2 & 1 & 0 & 80,95 & 100,00 \\
\hline $\begin{array}{l}\text { Laziska } \\
\text { Górne }\end{array}$ & 81,71 & 91,36 & 3 & 5 & 1 & 2 & 85,71 & 100,00 \\
\hline Mikołów & 80,94 & 97,46 & 5 & 7 & 1 & 1 & 80,95 & 95,24 \\
\hline
\end{tabular}


cd. tab. 5

\begin{tabular}{|l|c|c|c|c|c|c|c|c|}
\hline Myszków & 36,11 & 37,68 & 3 & 6 & 3 & 4 & 33,33 & 28,57 \\
\hline Orzesze & 65,09 & 95,16 & 3 & 10 & 2 & 2 & 71,43 & 100,00 \\
\hline Pszczyna & 70,28 & 71,85 & 4 & 13 & 1 & 3 & 69,57 & 86,96 \\
\hline Racibórz & 98,65 & 100 & 5 & 10 & 1 & 0 & 100,00 & 100,00 \\
\hline Rydułtowy & 79,77 & 89,87 & 4 & 4 & 2 & 1 & 85,71 & 95,24 \\
\hline Skoczów & 62,54 & 86,41 & 3 & 7 & 1 & 2 & 57,14 & 90,48 \\
\hline $\begin{array}{l}\text { Tarnowskie } \\
\text { Góry }\end{array}$ & 50,36 & 60,24 & 2 & 3 & 3 & 3 & 52,17 & 100,00 \\
\hline $\begin{array}{l}\text { Wodzisław } \\
\text { Śląski }\end{array}$ & 75,96 & 75,36 & 5 & 6 & 1 & 4 & 71,43 & 95,24 \\
\hline Zawiercie & 47,21 & 55,02 & 4 & 12 & 3 & 6 & 38,10 & 43,48 \\
\hline Żywiec & 61,44 & 66,53 & 4 & 6 & 3 & 3 & 71,43 & 95,24 \\
\hline ŚREDNIA & $\mathbf{7 1 , 9 9}$ & $\mathbf{7 8 , 1 8}$ & $\mathbf{3 , 3 6}$ & $\mathbf{7 , 1 8}$ & $\mathbf{1 , 6 4}$ & $\mathbf{2 , 5 5}$ & $\mathbf{7 3 , 7 7}$ & $\mathbf{8 5 , 0 3}$ \\
\hline
\end{tabular}

Źródło: Opracowanie własne na podstawie przeprowadzonych badań.

\section{Wyniki - wójtowie, burmistrzowie, prezydenci miast}

Wskazywane zależności nie do końca znajdują swoje odzwierciedlenie w odniesieniu do wójtów, burmistrzów i prezydentów miast. Zwycięzcy z komitetów lokalnych najlepszy wynik osiągali bowiem kolejno w gminach miejskich (96,8\%), wiejskich $(89,6 \%)$ oraz miejsko-wiejskich (85,7\%). Łącznie kandydaci lokalni objęli władzę w 146 na 167 badanych gmin i miast. Co ciekawe, przedstawiciele komitetów lokalnych dominują również w miastach na prawach powiatu $(63,2 \%)$. Konfrontacja tego odsetka z rezultatami komitetów partyjnych na poziomie rad sugeruje, że po ugruntowaniu swojej pozycji na lokalnej scenie politycznej część prezydentów wybranych początkowo z list partii politycznych rezygnuje z szyldu partyjnego. Niwelują tym samym ewentualne negatywne następstwa wskazywanej na początku artykułu niechęci obywateli do partii politycznych i potencjalnie poszerzają swój elektorat. Nie dziwi to zresztą. Jak bowiem wskazują badania, bezpartyjność prezydentów miast sprzyja reelekcji i wielokadencyjności (Drzonek, 2017; 2019). Oddziałuje na to również techniczna strona tych wyborów. Formuła większościowa zwiększa polityczną personalizację (tym samym potencjalnie ogranicza znaczenie szyldu partyjnego) oraz ułatwia zbudowanie silnej identyfikacji z lokalnym liderem. Często nie tylko skutkuje to tworzeniem komitetów wyborczych wyborców dominujących przez wiele lat na arenie lokalnej polityki (np. katowickie Forum Samorządowe i Piotr Uszok, a od 2018 r. Forum Samorządowe i Marcin Krupa czy Koalicja dla Gliwic Zygmunta Frankiewicza), ale wręcz zniechęca partie polityczne do startu wyborczego w danym mieście. 
Tabela 6

Zwycięzcy wyborów na urząd wójta, burmistrza i prezydenta miasta w województwie śląskim w odniesieniu do rodzaju gminy

\begin{tabular}{|l|c|c|c|c|}
\hline Zwycięzcy wyborów & $\begin{array}{c}\text { Wiejska } \\
(N=96)\end{array}$ & $\begin{array}{c}\text { Miejsko-wiejska } \\
(N=21)\end{array}$ & $\begin{array}{c}\text { Miejska } \\
(N=31)\end{array}$ & $\begin{array}{c}\text { Miasto na prawach } \\
\text { powiatu } \\
(N=19)\end{array}$ \\
\hline Zwycięzcy z komitetów lokalnych & $\begin{array}{c}86 \\
(89,6 \%)\end{array}$ & $\begin{array}{c}18 \\
(85,7 \%)\end{array}$ & $\begin{array}{c}30 \\
(96,8 \%)\end{array}$ & $\begin{array}{c}12 \\
(63,2 \%)\end{array}$ \\
\hline $\begin{array}{l}\text { Zwycięzcy z komitetów partyjnych } \\
\text { (ogólnopolskich i regionalnych) }\end{array}$ & $\begin{array}{c}10 \\
(10,4 \%)\end{array}$ & $\begin{array}{c}3 \\
(14,3 \%)\end{array}$ & $\begin{array}{c}1 \\
(3,2 \%)\end{array}$ & $\begin{array}{c}7 \\
(36,8 \%)\end{array}$ \\
\hline
\end{tabular}

Źródło: Opracowanie własne na podstawie przeprowadzonych badań.

Nieco inne wyniki przynosi analiza wyborów organu wykonawczego miast i gmin województwa śląskiego uwzględniająca liczbę mieszkańców. Zwycięzcy z komitetów lokalnych dominowali w gminach do 20000 , od 20001 do 50000 i od 50001 do 100000 mieszkańców. Największy odsetek zwycięzców z komitetów lokalnych odnotowano w gminach od 50001 do 100000 mieszkańców (100\%) i w gminach do 20000 mieszkańców (90,5\%). Sytuacja zmienia się jednak w miastach powyżej 100000 mieszkańców, w których zwycięzcy z komitetów lokalnych są w mniejszości w porównaniu ze zwycięzcami z komitetów ogólnopolskich i regionalnych $(41,7 \%)$. Może to sugerować, że w największych miastach rywalizacja polityczna $\mathrm{w}$ dużym stopniu zdominowana jest przez logikę partyjną. Sprzyja temu zresztą fakt, że właśnie tam partie mają zwykle najbardziej rozbudowane struktury, a więź wyborców z kandydatami (a nawet ich rozpoznawalność) jest mniejsza niż w mniejszych miejscowościach.

Tabela 7

Zwycięzcy wyborów na urząd wójta, burmistrza i prezydenta miasta w województwie śląskim w odniesieniu do wielkości badanej jednostki samorządu

\begin{tabular}{|l|c|c|c|c|}
\hline $\begin{array}{l}\text { Wwyelkość jednostki } \\
\text { samorządowej }\end{array}$ & $\begin{array}{c}\text { Do 20 000 } \\
\text { mieszkańców } \\
(N=126)\end{array}$ & $\begin{array}{c}20 \text { 001-50 000 } \\
\text { mieszkańców } \\
(N=17)\end{array}$ & $\begin{array}{c}50 \text { 001-100 000 } \\
\text { mieszkańców } \\
(N=12)\end{array}$ & $\begin{array}{c}\text { Powyżej 100 000 } \\
\text { mieszkańców } \\
(N=12)\end{array}$ \\
\hline $\begin{array}{l}\text { Zwycięzcy } \\
\text { z komitetów } \\
\text { lokalnych }\end{array}$ & $\begin{array}{c}114 \\
(90,5 \%)\end{array}$ & $\begin{array}{c}15 \\
(88,2 \%)\end{array}$ & $\begin{array}{c}12 \\
(100 \%)\end{array}$ & $\begin{array}{c}5 \\
(41,7 \%)\end{array}$ \\
\hline $\begin{array}{l}\text { Zwycięzcy } \\
\text { z komitetów } \\
\text { partyjnych } \\
\text { (ogólnopolskich } \\
\text { i regionalnych) }\end{array}$ & $\begin{array}{c}2 \\
(9,5 \%)\end{array}$ & $(11,8 \%)$ & 0 & 7 \\
\hline
\end{tabular}

Źródło: Opracowanie własne na podstawie przeprowadzonych badań. 


\section{Wnioski}

Wyniki przeprowadzonej analizy wpisują się w ustalenia innych badaczy (Gendźwiłł, Żółtak, 2020), świadczące o istnieniu relacji między wielkością gminy a poziomem odpartyjnienia samorządu gminnego mierzonego udziałem komitetów lokalnych w wyborach, poparciem dla tych komitetów oraz ich wynikiem mandatowym. W badanym studium przypadku mniejsza liczba mieszkańców jednostki samorządu terytorialnego wiązała się z mniejszą aktywnością komitetów ogólnopolskich i regionalnych oraz większym poparciem i liczbą mandatów w organie stanowiącym dla formacji lokalnych. Nie wpłynął na to specyficzny charakter elekcji samorządowej z 2018 roku, która (przynajmniej w przestrzeni medialnej) w dużej mierze zdominowana została przez ogólnopolską rywalizację między PiS a partiami opozycyjnymi. Choć znalazło to swój wyraz w wynikach wyborów sejmikowych (aż 544 z 552 mandatów obsadzonych przez partie ogólnopolskie), to nie odbiło się na kształcie scen politycznych miast i gmin województwa śląskiego. Dominacja formacji ogólnopolskich odnotowana została jedynie w miastach na prawach powiatu, szczególnie w miastach powyżej 100000 mieszkańców. W pozostałych badanych jednostkach samorządu mimo „plebiscytarnego" charakteru elekcji z 2018 roku dominują komitety lokalne. Dominacja ta nie jest już aż tak widoczna w odniesieniu do wójtów, burmistrzów i prezydentów miast. W tym wypadku nawet w miastach na prawach powiatu częściej w wyborach do organu stanowiącego wygrywają kandydaci komitetów lokalnych (często jednak mających status podmiotów pozornie bezpartyjnych). Prezydenci z „ogólnopolskimi szyldami” dominują (w stosunku 7 do 5) jedynie w miastach powyżej 100000 mieszkańców. Większych zmian $\mathrm{w}$ poziomie upartyjnienia miast $\mathrm{i}$ gmin nie spowodowała również nowelizacja prawa wyborczego. W miastach i gminach powyżej 20000 mieszkańców niemających statusu miast na prawach powiatu poparcie dla komitetów lokalnych i liczba mandatów zdobytych przez ich przedstawicieli nie odbiegała znacząco od wskaźników z poprzedniej elekcji.

Prezentowana analiza, jak większość tego typu badań, napotyka kilka ograniczeń. Po pierwsze, wnioski odnoszą się jedynie do województwa śląskiego, które jednak ze względu na swoją specyfikę (obecność zarówno niewielkich gmin wiejskich, jak i największej w Polsce liczby miast na prawach powiatu) stanowi naszym zdaniem odpowiedni wycinek do badania poziomu upartyjnienia (a w zasadzie odpartyjnienia) polityki samorządowej. Po drugie, w badaniach politologicznych trudno jednoznacznie wskazać kryterium, które świadczyłoby o bezpartyjności danego podmiotu polityki. W tej analizie zdecydowano się na wyodrębnienie dwóch kategorii komitetów: - partyjnych i lokalnych. Należy jednak podkreślić, że wśród tych drugich znalazły się zarówno podmioty, które nie posiadały żadnych powiązań z ugrupowaniami regionalnymi i ogólnopolski- 
mi, jak i takie, które w przeszłości takie powiązania wykazywały bądź zostały zarejestrowane jako komitety wyborcze wyborców przez członków tychże partii. Może to w pewien sposób zafałszować realną skalę odpartyjnienia samorządu (szczególnie w odniesieniu do największych miast). Trudno jednak stworzyć bezsprzeczny, zero-jedynkowy sposób odróżniania „prawdziwych” komitetów lokalnych i komitetów lokalnych z różnych przyczyn tworzonych przez lokalnych działaczy partyjnych.

\section{Bibliografia}

Balicki, R. (2018). Zmiana zasad tworzenia okręgów wyborczych w wyborach samorządowych w nowelizacji Kodeksu wyborczego z 2018 r., Przeglad Prawa Konstytucyjnego, 44 (4), s. 58-69.

CBOS. (2018). Wybory samorządowe - znaczenie, gotowość uczestnictwa i zainteresowanie decyzjami władz różnych szczebli. Komunikat z badań $n r$ 23. Warszawa: Centrum Badania Opinii Społecznej.

CBOS. (2019). Struktura sceny politycznej: partie bliższe i dalsze. Komunikat $z$ badań $n r$ 37. Warszawa: Centrum Badania Opinii Społecznej.

CBOS. (2020). Zaufanie społeczne. Komunikat z badań nr 43. Warszawa: Centrum Badania Opinii Społecznej.

Drzonek, M. (2017). Wielokadencyjność bez afiliacji partyjnej? Spostrzeżenia po reelekcjach „wiecznych prezydentów” w 2014 r. Przeglad Politologiczny, 1, s. $81-89$.

Drzonek, M. (2019). Im dłużej tym „bezpartyjniej”? Włodarze dużych miast w wyborach 2002-2018. Przeglad Politologiczny, 2, s. 123-140.

Flis, J. (2017). Zmiany systemu wyborczego 2018: analiza propozycji zawartych $w$ projekcie poselskim z 10 listopada 2017 roku. Warszawa: Fundacja Batorego.

Flis, J., Stolicki, D. (2019). JOW-y w gminach: lokalne partie władzy a nowe reguły rywalizacji. Ruch Prawniczy, Ekonomiczny i Socjologiczny, 799 (3), s. 253266.

Gendźwiłł, A. (2010). Bezpartyjni prezydenci miast i ich znaczenie dla lokalnej polityki. Studia Regionalne i Lokalne, 2, s. 99-120.

Gendźwiłł, A., Swianewicz (2017). Breeding Grounds for Local Independents, Bonus for Incumbents: Directly Elected Mayors in Poland. In: D. Sweeting (ed.), Directly Elected Mayors in Urban Governance: Impact and Practice, Bristol: Policy Press, s. 179-200.

Gendźwiłł, A., Żerkowska-Balas, M. (2018). Polacy o samorząach: opinia publiczna u progu samorzadowej kampanii wyborczej. Warszawa: Fundacja Batorego.

Gendźwił, A., Żółtak, T. (2016). Skutki wprowadzenia okręgów jednomandatowych w wyborach lokalnych. Studia Regionalne i Lokalne, 3, s. 94-116. 
Gendźwił, A., Żółtak, T. (2020). Ile partii w samorządzie? Partie sejmowe i listy lokalne w wyborach władz gmin w latach 2002-2018. Studia Regionalne i Lokalne, 2, s. 40-66.

Marmola, M. (2019). Nowe partie w systemach partyjnych państw Grupy Wyszehradzkiej. Toruń: Adam Marszałek.

Marmola, M. (2020). Poziom reprezentatywności partii politycznych i zapotrzebowanie na nowe ugrupowania w polskim systemie partyjnym. Wroctawskie Studia Politologiczne, 29, s. 49-57.

PAP (2018). Gdzie JOW-y. Zmiany w Kodeksie wyborczym - wybory proporcjonalne w 342 gminach. https://samorzad.pap.pl/kategoria/wybory/gdzie-jow-y-zmiany-w -kodeksie-wyborczym-wybory-proporcjonalne-w-342-gminach-lista (data dostępu: 13.12.2021). 